ROCZNIKI PSYCHOLOGICZNE/ANNALS OF PSYCHOLOGY

2020, XXIII, 4, 347-366

DOI: https://doi.org/10.18290/rpsych2 $0234-3$

\author{
MARTA ROKOSZ \\ RYSZARD POPRAWA \\ Institute of Psychology, University of Wrocław
}

\title{
A POLISH ADAPTATION AND VALIDATION OF THE DISTRESS TOLERANCE SCALE
}

\begin{abstract}
Distress Tolerance Scale (DTS; Simons \& Gaher, 2005) measures individual differences in experiencing and enduring negative emotional states. It consists of four dimensions: tolerance of perceived distress, assessment and acceptance of emotions, absorption of attention, and emotion regulation. The study aimed to evaluate the psychometric properties of a Polish adaptation of the Distress Tolerance Scale (DTS). A total of 1,210 individuals aged between 18 and 69 participated in the study (45\% men, $51 \%$ women). After obtaining a Polish translation, we conducted EFA and CFA to examine the validity of the construct. EFA revealed a two-factor structure of the DTS, with Regulation as a separate factor. The original and modified CFA model with Regulation as a separate first-order factor showed an unsatisfactory fit to the data. Better CFA parameters were obtained with the reduced, three-factor version of the DTS. Four- and three-factor versions both show good internal consistency, temporal stability, convergent, and discriminant validity, with the exception of the Regulation subscale. As expected, distress tolerance is positively associated with positive affectivity, satisfaction with life, and self-control ability, but negatively with negative affectivity, perceived stress, and difficulties in emotion regulation. Men declared higher levels of distress tolerance than women. The Regulation subscale showed the weakest validity results; in terms of content, it seems to deviate from the concept of distress tolerance. With all those findings in mind, we recommend the valid and reliable three-factor version to be used in further studies.
\end{abstract}

Keywords: distress; distress tolerance; Polish adaptation; questionnaire validity.

Correspondence concerning this article can be sent to MARTA RoKOsz, MA, Institute of Psychology, University of Wrocław, ul. Dawida 1, 50-527 Wrocław, Poland; e-mail: marta.rokosz @uwr.edu.pl; ORCID: https://orcid.org/0000-0002-0194-7680; RYSZARD POPRAWA, PhD, ORCID: https://orcid.org/0000-0002-3711-8710.

All procedures performed in studies involving human participants were in accordance with the ethical standards of the institutional and/or national research committee and with the 1964 Helsinki Declaration and its later amendments or comparable ethical standards. This article does not contain any studies with animals performed by any of the authors. Informed consent was obtained from all individual participants included in the study. 
Distress tolerance (DT) is an emotional and cognitive ability to withstand negative psychological states (Simons \& Gaher, 2005). Research indicates the influence of low distress tolerance on the formation and development of a wide range of mental disorders (Leyro et al., 2010; McHugh \& Otto, 2012). The inability to tolerate emotional distress is associated, among others, with an increased sensitivity to anxiety symptoms (Keoughet al., 2010), the use of psychoactive substances (Azizi, 2010; Brown et al., 2005; Leyro et al., 2011; Sandín et al., 2017; Shadur et al., 2017; Simons \& Gaher, 2005), eating disorders (Anestis et al., 2007), and problematic Internet use (Akbari, 2017).

According to Simons and Gaher (2005), distress tolerance consists of subjective assessments and expectations of experiencing negative emotional states and manifests in four areas. First, it includes the perceived tolerance ability and aversiveness of feelings, i.e., the extent to which a person perceives distress as bearable (tolerance). Second, it concerns the assessment of distress, acceptance of emotions, and the perception of one's ability to deal with it in comparison to other people (appraisal). The third aspect is the tendency to absorb attention and disrupt functioning (absorption). The last, fourth area concerns the regulation of emotion, in other words, the degree to which an individual avoids or faces the perceived distress along with the ways and speed of alleviating these states (regulation). According to this concept, people with low distress tolerance describe this state as difficult to endure, do not accept the feelings that accompany them, consider these feelings as shameful, and assess their coping skills as inferior to others. They put great effort into avoiding unpleasant emotions and implement immediate methods of relief. When they are not able to alleviate the unpleasant emotional states, they have a sense of being absorbed by their feelings, and their functioning significantly deteriorates.

To measure distress tolerance conceptualized in this way, Simons and Gaher (2005) developed a 15-item questionnaire, the Distress Tolerance Scale (DTS). Using factor analysis, the authors confirmed the assumed 4-factor structure of the tool, i.e., tolerance, appraisal, absorption, and regulation, with a higher-order factor in the form of general distress tolerance. This model provided a better fit for data than the initial single factor solution, suggested by EFA. The studies showed that there was a high internal consistency of the overall DTS score $(\alpha \geq .82)$ and subscales, with $\alpha \geq .72$ for Tolerance, $\geq .82$ for Appraisal, $\geq .78$ for Absorption, and $\geq .70$ for Regulation. Temporal stability, measured with a 6-month test-retest, was intra-class $r=.61$. Validity analyzes were first conducted for the overall DTS score. Distress tolerance was negatively associated with negative affectivity, emotional lability, alcohol and marijuana use, and 
motives of using psychoactive substances to cope. It was positively associated with positive affectivity (Simons \& Gaher, 2005). The next step of validity analysis involved assessment of correlations for individual subscales. The validity variables were negative affectivity and variables connected to alcohol use. Tolerance, Appraisal, and Absorption correlated relatively highly (from -.40 to -.61) with negative affectivity. Regulation, however, was associated weakly $(r=-.25)$ with negative affectivity. Variables measuring alcohol use were not associated with DTS subscales at all, or the correlations were very weak (from -.12 to -.20) (Simons \& Gaher, 2005).

The DTS has been adapted into several languages, including Persian (Azizi, 2010), Chinese (You \& Leung, 2012), French (Wagener \& Blairy, 2015), and Spanish (Sandín et al., 2017). They obtained similar reliability indicators, with Cronbach's $\alpha$ for the subscales ranging from .70 to .89. Cronbach's $\alpha$ has been measured for the overall DTS score in the original version (from .82 to .85 ), French $(\alpha=.93)$ and Chinese $(\alpha=.91)$. Temporal stability, in the adaptations that used it, reached between .48 and .79 , except for the Chinese version, where it ranged between .31 and .48. It should be noted that the Regulation subscale obtained the weakest test-retest correlation coefficients.

Although French and Spanish adaptations supported its originally hypothesized hierarchical, 4- factor structure (Wagener \& Blairy, 2015; Sandin et al., 2017), in the Chinese study this model presented a poor fit to the data (You \& Leung, 2012). Chinese researchers were the only ones to conduct an EFA, which revealed a 2 -factor solution. Factor 1 consisted of the original Tolerance and Absorption subscales, and most items from the Appraisal subscale. Factor 2 consisted of the original Regulation subscale and the remaining item from the Appraisal subscale. Those findings compelled You \& Leung (2012) to test the modified model, in which Tolerance, Appraisal, and Absorption comprised the second-order factor of General Distress Intolerance. Meanwhile, the Regulation subscale (additionally loaded by one item from the Appraisal subscale) was included as an independent first-order factor correlated with General Distress Intolerance. CFA results for that model showed much better fit indices than the remaining models: 1-, 2-factor and original (You \& Leung, 2012). No factor analyzes were conducted in the Persian version of the DTS (Azizi, 2010). 


\begin{abstract}
AIM OF THE STUDY
This paper presents an adaptation and validation of the Polish version of the DTS. To examine validity, it was assumed that (H1) the Polish version supports its original, 4-factor structure, with a higher-order factor of Distress Tolerance (Simons \& Gaher, 2005). To examine the convergent validity, it was hypothesized, in line with Simons and Gahers' (2005) findings, that (H2) DTS is positively associated with positive affectivity (Watson et al., 1988). Distress tolerance is presented as a mental health and coping resource (Simons \& Gaher, 2005), which is why we expected (H3) positive association of DTS with self-control ability (Tangney et al., 2004) and (H4) satisfaction with life (Diener et al., 1985). We also expected (H5) negative associations of the DTS with negative affectivity (Watson et al., 1988), (H6) perceived stress (Cohen \& Wiliamson, 1988), and (H7) difficulties in emotion regulation (Gratz \& Roemer, 2004), which would support the discriminant validity of the tool.

Moreover, in line with the previous studies (Sandín et al., 2017; Simons \& Gaher, 2005), we expected (H6) significant gender differences in the DTS results, namely that men will report a higher degree of distress tolerance than women.
\end{abstract}

\title{
METHOD
}

\section{Participants and Procedure}

A total of 1,210 participants aged between 18 and 69 took part in the study $(M=24.76 ; S D=8.66)$, of which $45 \%$ were men and $51 \%$ women (48 participants did not indicate their gender). The majority $(61 \%)$ of the sample were students, $4 \%$ had primary or secondary education, $3 \%$ had basic vocational education, $13 \%$ had a bachelor or engineering degree, and $13 \%$ had higher education. The educational background of 61 participants was not identified. Despite the lack of some demographic information but given the completeness of other data they were included in the analysis.

The study was conducted in a few stages. At the first stage, a research team consisting of four psychologists, fluent in English and an Anglicist prepared independent translations of the DTS. Then, based on the assumptions of the distress tolerance concept (Simons \& Gaher, 2005), the team discussed and worked out the final version of the questionnaire. The translation was then subjected 
to the study of temporal stability by a bilingual response method (Hornowska \& Paluchowki, 2004) conducted on a sample of 29 final year English philology students. The sample consisted of 4 women and 25 men, aged 22 to 26 $(M=23.24 ; S D=1.22)$. Half of the respondents were given a Polish version of the questionnaire, and the other half received an English one. After two weeks, the test was repeated, and participants filled the opposite version of the DTS.

At the second stage, to measure temporal stability, 51 participants (45 women and 6 men), aged 18 to $35(M=19.78 ; S D=2.43)$, completed the Polish translation of the DTS twice, with an interval of two weeks between the test and retest (Hornowska, 2009).

We measured the validity and reliability of the DTS on the previously described group of participants $(N=1,210)$. First, we conducted an EFA on the data acquired from the first 150 participants (47\% women and $43 \%$ men) aged from 18 to $68(M=26.68 ; S D=11.63)$. We excluded this group from further analysis.

Then, on the remaining data, we conducted a hierarchical CFA to examine the construct validity of the tool. The convergent and discriminant validity was examined based on the following indicators: positive and negative affectivity $(N=431)$, self-control $(N=811)$, satisfaction with life $(N=343)$, perceived stress $(N=254)$, and difficulties in emotion regulation $(N=342)$.

The study was anonymous, with voluntary participation. We informed the participants that they were taking part in the validation study of psychological measures. The participants were obtained in groups, among first-year psychology students, and individually by the cooperating research team of students.

\section{Measures}

Distress Tolerance Scale (DTS; Simons \& Gaher, 2005). It is a 15 -item self-report questionnaire measuring 4 aspects of distress tolerance: tolerance (3 items); appraisal (6 items); absorption (3 items); and regulation (3 items). The items are rated on a 5-point Likert scale ranging from (1) strongly agree to (5) strongly disagree, and they can be found in Table 1. Higher scores represent higher distress tolerance. The DTS demonstrates good internal consistency and a 6-month test-retest reliability of .61 (Simons \& Gaher, 2005). Language equivalence analysis on a group of English philology students $(N=29)$ showed high correlations between the original and Polish version (from .69 to .82).

Self-Control Scale (SCS; Tangney et al., 2004). It consists of 36 items assessing the ability to control or change one's internal reactions, as well as to stop 
undesired behavioral tendencies and to inhibit their manifestation. Participants rate the items on a 5-point Likert scale from (1) not at all like me to (5) very much like me. The Polish version of the SCS (Poprawa, 2016) used in this study shows good internal consistency (Cronbach's $\alpha=.90$ ).

Difficulties in Emotion Regulation Scale (DERS; Gratz \& Roemer, 2004). It consists of 36 items, which form 6 factors meant to measure emotional deregulation: nonacceptance of emotional responses, difficulties engaging in goaldirected behavior, impulse control difficulties, lack of emotional awareness, limited access to emotion regulation strategies and lack of emotional clarity. Participants are supposed to assess how often the items apply to themselves, on a scale from (1) almost never (0-10\%) to (5) almost always (91-100\%). The Polish validation of the DERS (Dragan, 2016) confirmed the original factor structure and demonstrated good internal consistency, $\alpha$ ranging from .64 to .90 for the subscales and .93 for the general score.

Positive and Negative Affect Scale (PANAS; Watson et al., 1988). It is a 30-item questionnaire assessing positive and negative affectivity. Participants rate the items on a 5-point Likert scale, to what extent they usually feel certain emotional states expressed by adjectives such as active, nervous, scared, etc. The Polish version (Brzozowski, 2010) showed a good internal consistency, with $\alpha$ ranging from .73 to .95 .

Perceived Stress Scale (PSS-10; Cohen \& Williamson, 1988). It measures the extent to which a person appraises life situations as stressful. 10 items are rated on a 5-point Likert scale, ranging from (0) never to (4) very often. Cronbach's $\alpha$ in the Polish version (Juczyński \& Ogińska-Bulik, 2009) was .86, which showed a good internal consistency, and a 4-week test-retest reliability was .72.

Satisfaction with Life Scale (SWLS; Diener et al., 1985). It is a 5-item questionnaire assessing global satisfaction with life. Participants rate items on a 7-point Likert scale, ranging from (1) strongly disagree to (7) strongly agree. The Polish version (Juczyński, 2001) demonstrates a good internal consistency $(\alpha=.81)$ and a 2 -week test-retest reliability of .86 .

\section{Data Analysis}

The TIBCO Software Statistica version 13.3 and IBM SPSS AMOS version 25 were used to perform analyses.

We performed an exploratory factor analysis (EFA) using the principal axis factoring (PAF) with Varimax rotation. It is the best method to detect structure 
in relationships between variables. The factorability of the data was revealed by the Kaiser-Meyer-Olkin test and Cattell's scree test (Statsoft, 2013).

Hierarchical CFA was performed using the generalized least squares method. We used various goodness of fit indices. Instead of using biased $\chi^{2}$ statistics, we used the $\chi^{2} / d f$ index, which reduces the limitation of $\chi^{2}$ statistics and should not exceed 3.0. The standardized root mean square residual (SRMR) and minimum fit function $(F M I N)$ should be as close to zero as far as possible and should not exceed .08. The root mean square error of approximation (RMSEA) should be as small as possible, and its value $<.08$ is acceptable. Values below .05 indicate a very good fit. The Goodness-of-fit index (GFI), adjusted Goodness-of-fit index (AGFI), and comparison-of-fit index (CFI) should be above .90 , preferably $>.95$ (Bedyńska \& Książek, 2012; Schreiber et al., 2006). We compared three models: the original, hierarchical 4-factor model (A); a hierarchical, modified model (B); and a reduced, hierarchical, 3 -factor model (C).

We assessed reliability based on the following indicators: absolute temporal stability measured by Pearson's $r_{t r}$ between test and retest results, both for the subscales and the overall result; Cronbach's $\alpha$ (internal consistency), both for subscales and the general result, and item-total correlation within each subscale $\left(r_{i t}\right)$.

Discriminant and convergent validity were examined using Pearson's correlation coefficient. Gender differences were assessed using the Mann-Whitney $U$ test.

\section{RESULTS}

\section{Factor Structure of the Polish DTS}

Exploratory Factor Analysis (EFA). To examine the factor structure of the Polish DTS, we first conducted an EFA on a randomly chosen group of 150 participants. The results of this analysis are presented in Table 1. The criteria we adopted revealed a two-factor solution. Factor 1 , with the eigenvalue $=4.68$, consisted of Tolerance, Appraisal, and Absorption subscales. The factor loadings of the items ranged from .38 to .74 and this component accounted for $31 \%$ of the total variance. Factor 2 (eigenvalue $=1.64$ ) explained $11 \%$ of the variance and consisted solely of the Regulation subscale, with factor loadings of the items ranging from .62 to .69 . 
Table 1. EFA and CFA Factor Loadings in Models A and C and Results of Reliability Analysis

\begin{tabular}{|c|c|c|c|c|c|c|c|c|}
\hline \multirow{3}{*}{$\begin{array}{l}\text { Sub- } \\
\text { scale }\end{array}$} & \multirow{3}{*}{ Items } & \multicolumn{2}{|c|}{$\mathrm{EFA}(N=150)$} & \multicolumn{2}{|c|}{ CFA $(N=1,060)$} & \multirow{2}{*}{\multicolumn{2}{|c|}{$N=1,060$}} & \multirow{3}{*}{$\begin{array}{r}N=51 \\
r_{t r}\end{array}$} \\
\hline & & \multirow{2}{*}{$\begin{array}{cc}\mathrm{F} 1 \\
\beta \\
\end{array}$} & \multirow{2}{*}{$\begin{array}{cl}\mathrm{F} 2 \\
\beta \\
\end{array}$} & \multirow{2}{*}{$\frac{\text { Models A \& B }}{\beta}$} & \multirow{2}{*}{$\frac{\text { Model C }}{\beta}$} & & & \\
\hline & & & & & & $r_{i t}$ & $\alpha$ & \\
\hline \multirow{3}{*}{$\frac{\mathscr{\Xi}}{\stackrel{\Xi}{\Xi}}$} & $\begin{array}{l}\text { 1. Feeling distressed or upset is unbearable to me. } \\
\text { Odczuwanie zmartwienia i zdenerwowania jest dla mnie nie do zniesienia. }\end{array}$ & .65 & .15 & .70 & .70 & .57 & & \\
\hline & $\begin{array}{l}\text { 3. I can't handle feeling distressed or upset. } \\
\text { Nie umiem poradzić sobie ze zmartwieniem lub zdenerwowaniem. }\end{array}$ & .73 & -.10 & .81 & .81 & .58 & .72 & .73 \\
\hline & $\begin{array}{l}\text { 5. There's nothing worse than feeling distressed or upset. } \\
\text { Nie ma nic gorszego niż zmartwienie lub zdenerwowanie. }\end{array}$ & .52 & .31 & .61 & .59 & .49 & & \\
\hline \multirow{6}{*}{ 离 } & $\begin{array}{l}\text { 6. I can tolerate being distressed or upset as well as most people. } \\
\text { Jestem w stanie znosić zmartwienie lub zdenerwowanie równie dobrze jak większość ludzi. }\end{array}$ & .51 & .11 & .60 & .61 & .51 & \multirow{6}{*}{.83} & \multirow{6}{*}{.66 } \\
\hline & $\begin{array}{l}\text { 7. My feelings of distress or being upset are not acceptable. } \\
\text { Moje uczucia zmartwienia lub zdenerwowania są nie do zaakceptowania. }\end{array}$ & .56 & .25 & .65 & .65 & .57 & & \\
\hline & $\begin{array}{l}\text { 9. Other people seem to be able to tolerate feeling distressed or upset better than I can. } \\
\text { Wydaje mi się, że inni są w stanie lepiej niż ja znosić zmartwienie lub zdenerwowanie. }\end{array}$ & .62 & -.02 & .68 & .69 & .60 & & \\
\hline & $\begin{array}{l}\text { 10. Being distressed or upset is always a major ordeal for me. } \\
\text { Bycie zmartwionym lub zdenerwowanym jest dla mnie zawsze ciężkim doświadczeniem. }\end{array}$ & .67 & .22 & .77 & .77 & .64 & & \\
\hline & $\begin{array}{l}\text { 11. I am ashamed of myself when I feel distressed or upset. } \\
\text { Jestem zawstydzony sobą, kiedy czuję się zmartwiony lub zdenerwowany. }\end{array}$ & .38 & .04 & .64 & .64 & .55 & & \\
\hline & $\begin{array}{l}\text { 12. My feelings of distress or being upset scare me. } \\
\text { Moje uczucia zmartwienia lub zdenerwowania przerażają mnie. }\end{array}$ & .61 & .24 & .81 & .80 & .70 & & \\
\hline \multirow{3}{*}{ 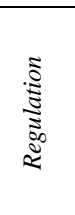 } & $\begin{array}{l}\text { 8. I'll do anything to avoid feeling distressed or upset. } \\
\text { Zrobię wszystko, aby uniknąć zmartwienia lub zdenerwowania. }\end{array}$ & .05 & .67 & .58 & - & .55 & \multirow{3}{*}{.76} & \multirow{3}{*}{.59} \\
\hline & $\begin{array}{l}\text { 13. I'll do anything to stop feeling distressed or upset. } \\
\text { Zrobię wszystko, by przestać czuć się zmartwionym lub zdenerwowanym. }\end{array}$ & .05 & .69 & .88 & - & .69 & & \\
\hline & $\begin{array}{l}\text { 14. When I feel distressed or upset, I must do something about it immediately. } \\
\text { Kiedy jestem zmartwiony lub zdenerwowany, muszę natychmiast coś z tym zrobić. }\end{array}$ & .13 & .62 & .60 & - & .55 & & \\
\hline \multirow{3}{*}{ 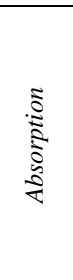 } & $\begin{array}{l}\text { 2. When I feel distressed or upset, all I can think about is how bad I feel. } \\
\text { Kiedy jestem zmartwiony lub zdenerwowany, jestem w stanie myśleć tylko o tym, jak źle się czuję. }\end{array}$ & .74 & .13 & .82 & .83 & .70 & \multirow{3}{*}{.81} & \multirow{3}{*}{.75} \\
\hline & $\begin{array}{l}\text { 4. My feelings of distress are so intense that they completely take over. } \\
\text { Moje zdenerwowanie bywa tak silne, że całkowicie mnie opanowuje. }\end{array}$ & .68 & .06 & .76 & .75 & .63 & & \\
\hline & $\begin{array}{l}\text { 15. When I feel distressed or upset, I cannot help but concentrate on how bad the distress actually } \\
\text { feels. } \\
\text { Kiedy jestem zmartwiony lub zdenerwowany, nie mogę powstrzymać się przed skupianiem na tym, } \\
\text { jak bardzo źle się czuję. }\end{array}$ & .70 & .04 & .78 & .78 & .66 & & \\
\hline
\end{tabular}

Note. Model A = original, hierarchical, 4-factor; Model B = hierarchical, 2-subfactor; Model C = reduced, hierarchical, 3-factor.

$\beta=$ standardized regression weights; $r_{i t}=$ item-total correlation; $r_{t r}=$ test-retest correlation; $\alpha=$ Cronbach's alpha. All coefficients are statistically significant at $p<.001$. 
Confirmatory Factor Analysis (CFA). Using a hierarchical CFA, we tested Model A consistently with the original assumptions, with DT being a latent variable of the second-order, and Tolerance, Appraisal, Absorption, and Regulation being the latent variables of the first order.

Due to the EFA revealing Regulation as an independent factor, similar to the Chinese findings (You \& Leung, 2012), we tested modified Model B. DT, as a higher-order factor, consisted of three first-order factors: Tolerance, Appraisal, and Absorption. Regulation was an independent first-order factor and it correlated with DT. The indexes of fitness for both models (A and B) were identical (see Table 2). Standardized factor loadings were significant $(p<.001)$ and ranged from .58 to .88 (see Table 1). The three first-order factors significantly $(p<.001)$ and very strongly loaded the second-order factor of DT: Tolerance 1.0, Absorption .95, and Appraisal .96, each with $R^{2}>.95$. Regulation in the model A loaded DT with $\beta=.45$ and $R^{2}=.20(p<.001)$. In Model $\mathrm{B}$, Regulation as an independent first-order factor was significantly correlated with DT $(r=.45, p<.001)$.

None of the tested models (A and B) showed satisfyingly high fit indices (see Table 2).

Table 2. Summary of CFA Results of Three Models of Polish DTS

\begin{tabular}{cccccccc}
\hline Model & $\chi^{2}(d f)$ & $\chi^{2} / d f$ & SRMR & RMSEA & GFI & AGFI & FMIN \\
\hline 1. Model A & $491.66(86)^{* * *}$ & 5.72 & .10 & .07 & .94 & .91 & .46 \\
2. Model B & $491.66(86)^{* * *}$ & 5.72 & .10 & .07 & .94 & .91 & .46 \\
3. Model C & $329.31(51)^{* * *}$ & 6.45 & .06 & .07 & .95 & .92 & .31 \\
\hline
\end{tabular}

Note. Model A = original, hierarchical, 4-factor; Model B = hierarchical, 2-subfactor; Model $\mathrm{C}=$ reduced, hierarchical, 3-factor.

${ }^{* * * *} p<.001$.

The Regulation subscale was revealed as a factor separate from DT by the EFA, both in our analyzes and in the Chinese study (You \& Leung, 2012), and accounted for very little of the DT variance $\left(R^{2}=.20\right)$. Based on those findings, we decided to test a reduced model without this component. In the reduced model (C), the second-order factor (DT) consisted of three subfactors: Tolerance, Appraisal, and Absorption. As presented in Table 2, the reduced model fit the data slightly better than the other two models. All factor loadings were significant $(p<.001)$ and ranged from .59 to .83 (see Table 1). All three first-order 
factors loaded the second-order factor (DT) very highly: Tolerance $1.0 ; R^{2}=1.0$, Absorption .95; $R^{2}=.90$ and Appraisal $.95 ; R^{2}=.90(p<.001)$.

Reliability. The results of the reliability analysis of the DTS are presented in Table 1. We calculated Cronbach's $\alpha$ on the data from the sample of $N=1,060$. The alpha coefficients were high for each subscale, ranging from .72 to .83 . Item-total correlations for all subscales were also high, from .49 to .70 . Cronbach's $\alpha$ for the overall DTS score in the original model (A) was .90, and the item-total correlation ranged from .32 to .72 . The Regulation subscale had the weakest item-total correlation coefficients (item $8=.32$, item $13=.46$, and item $14=.32$ ). In the reduced model $(\mathrm{C})$ Cronbach's $\alpha$ for the overall score was .91. The item-total correlation coefficients were also high and ranged from .52 to .72 .

Temporal stability analysis $(N=51)$ showed a high test-retest correlation coefficients, ranging from .59 for the Regulation subscale to .75 for the Absorption subscale $(p<.001)$ (see Table 1$)$.

Validity. Table 3 presents the results of correlation analyzes of the criterion validity for the subscales and the overall DTS results in Model A (original) and Model C (reduced). In the aspect of convergent validity, DTS and most of its subscales correlated positively with self-control ability, positive affectivity, and satisfaction with life. Only the Regulation subscale (in Model A) did not correlate significantly with self-control ability and satisfaction with life. However, it correlated negatively with positive affectivity $(r=-.17)$. The correlations of the overall DTS score with the mentioned variables are generally average and nominally higher in Model C than in Model A.

In terms of discriminant validity, the overall DTS score correlated significantly and negatively with negative affectivity, perceived stress, and difficulties with emotion regulation. Those correlations were mostly high, ranging from -.32 to -.64 in Model A and from -.39 to -.72 in Model C. Generally, relationships of the DTS with the analyzed variables were nominally stronger in Model C than in Model A. The results presented in Table 3 show that the Regulation subscale, contrary to the other subscales, did not correlate significantly with perceived stress, nor with Lack of Emotional Clarity (one of the Difficulties with Emotion Regulation compounds). Of all the DERS factors, only Lack of Emotional Awareness did not show any significant relationships with the overall DTS score, nor with its subscales (see Table 3). 
Table 3. Descriptive Statistics ( $M$ and SD) and Correlation Matrix of Observed Variables

\begin{tabular}{|c|c|c|c|c|c|c|c|}
\hline \multirow{2}{*}{ Variable } & \multirow{2}{*}{$M(S D)$} & \multicolumn{4}{|c|}{ Subscale } & \multicolumn{2}{|c|}{ Total } \\
\hline & & $\mathrm{T}$ & A & Abs & $\mathrm{R}$ & Model A & Model C \\
\hline Tolerance & $3.35(0.95)$ & - & & & & & \\
\hline Appraisal & $3.42(0.85)$ & .73 & - & & & & \\
\hline Absorption & $3.27(1.04)$ & .72 & .73 & - & & & \\
\hline Regulation & $2.93(0.95)$ & .38 & .35 & .26 & - & & \\
\hline Total DTS: Model A & $3.24(0.76)$ & .88 & .87 & .85 & .62 & - & \\
\hline Total DTS: Model C & $3.35(0.86)$ & .90 & .90 & .91 & - & .96 & - \\
\hline Self-control & $112.89(19.21)$ & .27 & .29 & .37 & $.03^{\mathrm{ns}}$ & & .35 \\
\hline \multicolumn{8}{|l|}{ Affectivity } \\
\hline Positive & $49.13(9.60)$ & .21 & .22 & .21 & -.17 & $.14^{* *}$ & .23 \\
\hline Negative & $32.87(12.21)$ & -.48 & -.51 & -.48 & $-.11^{* *}$ & -.50 & -.54 \\
\hline Perceived stress & $18.89(7.01)$ & -.44 & -.46 & -.48 & $-.08^{\mathrm{ns}}$ & -.47 & -.51 \\
\hline Satisfaction with Life & $20.55(5.30)$ & .27 & .28 & .32 & $-.01^{\mathrm{ns}}$ & .26 & .31 \\
\hline \multicolumn{8}{|l|}{ Difficulties in emotion regulation } \\
\hline $\begin{array}{l}\text { Nonacceptance } \\
\text { of Emotional Responses }\end{array}$ & $12.47(5.14)$ & -.43 & -.57 & -.47 & -.27 & -.51 & -.52 \\
\hline $\begin{array}{l}\text { Difficulties Engaging } \\
\text { in Goal-Directed Behavior }\end{array}$ & $13.71(4.72)$ & -.48 & -.50 & -.57 & -.21 & -.53 & -.56 \\
\hline $\begin{array}{l}\text { Impulse Control } \\
\text { Difficulties }\end{array}$ & $11.65(4.34)$ & -.49 & -.55 & -.55 & $-.16^{* *}$ & -.52 & -.57 \\
\hline Lack of Emotional Awareness & $14.22(3.10)$ & $-.07^{\mathrm{ns}}$ & $-.09^{\mathrm{ns}}$ & $-.05^{\mathrm{ns}}$ & $.07^{\mathrm{ns}}$ & $-.04^{\mathrm{ns}}$ & $-.07^{\mathrm{ns}}$ \\
\hline $\begin{array}{l}\text { Limited Access } \\
\text { to Emotion Regulation Strategies }\end{array}$ & $17.08(6.34)$ & -.60 & -.68 & -.71 & $-.17^{* *}$ & -.64 & -.72 \\
\hline Lack of Emotional Clarity & $9.66(3.62)$ & -.31 & -.40 & -.37 & $.00^{\mathrm{ns}}$ & -.32 & -.39 \\
\hline Overall result & $13.13(3.31)$ & -.59 & -.69 & -.68 & -.20 & -.64 & -.70 \\
\hline
\end{tabular}

Note. Model $\mathrm{A}=$ original, hierarchical, 4 -factor; Model $\mathrm{C}=$ reduced, hierarchical, 3 -factor. $\mathrm{T}=$ Tolerance, $\mathrm{A}=$ Appraisal, $\mathrm{Abs}=$ Absorption, $\mathrm{R}=$ Regulation .

Unmarked statistical indicators are significant at $p<.001$; others: ${ }^{*} p<.05,{ }^{* *} p<.01 ;$ ns $=$ nonsignificant. 


\section{Descriptive Statistics and Gender Differences}

Descriptive statistics of the overall result of the Polish version of the DTS (in both Model A and C) and its subscales, tested separately for women and men, can be found in Table 4, along with the results of the analysis of gender differences. None of the scores had a normal distribution, as indicated by the significance of Kolmorov-Smirnov's test (with Lilliefors correction). For both women and men, the distributions were left-sided asymmetric and more flattened than in a normal distribution. Consequently, the participants generally answered with higher DTS scores. The Mann-Whitney $U$ test indicated that men, globally and in separate subscales, obtained higher results than women $(p<.01)$. However, there were no gender differences in Regulation subscale.

Table 4. Descriptive Statistics and Gender Differences in Results of Reduced Polish Version of DTS

\begin{tabular}{|c|c|c|c|c|c|c|c|c|c|c|c|}
\hline \multirow{2}{*}{ Scale } & \multicolumn{5}{|c|}{ Women $(N=573)$} & \multicolumn{5}{|c|}{$\operatorname{Men}(N=536)$} & \multirow{2}{*}{$z$} \\
\hline & $M$ & $S D$ & $A$ & $K$ & $d$ & $M$ & $S D$ & $A$ & $K$ & $d$ & \\
\hline Tolerance & 3.28 & 0.91 & -.25 & -.48 & $.10^{* * *}$ & 3.46 & 0.99 & -.44 & -.42 & $.11^{* * *}$ & $3.35^{* * *}$ \\
\hline Appraisal & 3.40 & 0.83 & -.32 & -.29 & $.06^{* *}$ & 3.50 & 0.85 & -.54 & -.13 & $.09^{* *}$ & $2.48^{* *}$ \\
\hline Absorption & 3.16 & 1.04 & -.22 & -.75 & $.10^{* *}$ & 3.42 & 1.03 & -.38 & -.65 & $.13^{* *}$ & $4.07^{\text {*** }}$ \\
\hline Regulation & 2.91 & 0.92 & -.07 & -.51 & $.09^{* *}$ & 2.95 & 0.98 & .01 & -.75 & $.09^{* *}$ & $0.46^{\mathrm{ns}}$ \\
\hline $\begin{array}{l}\text { Total } \\
\text { (Model A) }\end{array}$ & 3.19 & 0.73 & -.16 & -.28 & $.04^{*}$ & 3.33 & 0.78 & -.37 & -.28 & $.05^{* *}$ & $3.50^{* * *}$ \\
\hline $\begin{array}{l}\text { Total } \\
\text { (Model C) }\end{array}$ & 3.28 & 0.83 & -.28 & -.41 & $.06^{* *}$ & 3.46 & 0.87 & -.48 & -.33 & $.08^{* *}$ & $3.79^{* * *}$ \\
\hline
\end{tabular}

Note. $M=$ mean, $S D=$ standard deviation, $A=$ asymmetry, $K=$ kurtosis, $d=$ Kolmogorov-Smirnov normality of distribution test with Lilliefors correction, $z=$ value of Mann-Whitney $U$ test.

${ }^{*} p<.05,{ }^{* *} p<.01,{ }^{* * *} p<.001 ; \mathrm{ns}=$ nonsignificant.

\section{DISCUSSION}

According to theoretical assumptions and research results of Simons and Gaher (2005), DTS should measure four independent aspects of distress tolerance: Tolerance, Appraisal, Absorption, and Regulation, which combine into a common factor of a higher-order, i.e. Distress Tolerance. This is reflected by the first of the tested hypotheses (H1). To support this hypothesis, in line with the original (Simons \& Gaher, 2005), Chinese (You \& Leung, 2012), and French 
(Wagener \& Blairy, 2015) studies, we first performed an EFA. We applied principal axis factoring (PAF), which allows separate factors in the structure of the rotated matrix of variables to be extracted (StatSoft, 2013). The results revealed a two-factor solution, similar to the results of the Chinese study (You \& Leung, 2012), with the first factor consisting of Tolerance, Appraisal, and Absorption, and the second factor consisting solely of the Regulation subscale. In the next step, we conducted a CFA on the original model (A) identified by Simons and Gaher (2005). Based on our EFA results and the Chinese study (You \& Leung, 2012), we also conducted CFA on the modified model (B), in which Regulation was a separate first-factor order correlated with DT. Both models showed identical, significant, and satisfying factor loadings (Table 1), but their goodness-of-fit indexes were not fully satisfactory (Table 2). The Regulation subscale in Model A correlated to the first-order factor (DT) the weakest out of all the subscales, accounting only for $20 \%$ of the variance (while the other subscales explained $>95 \%$ of the variance). In the modified model (B) second-order factor Regulation correlated with DT positively, but only on an average level $(r=.45$; $p<.001$ ), although we expected high correlations. Additionally, the Regulation subscale had the weakest correlations with the other subscales $(r<.40)$ in the original model (A). It correlated with the overall DTS score with $r=.62$, which was significantly weaker $(p<.01$, one-sided test) than the correlations of the remaining subscales. As presented in Table 3, Tolerance, Appraisal, and Absorption were very highly correlated with each other $(r \geq .70)$ and with the overall score $(r \geq .85)$. Similar results, showing weak relationships of the Regulation subscales with DT and its components, were obtained in the original study (Simons \& Gaher, 2005) and the other adaptations (Sandín et al., 2017; Wagener \& Blairy, 2015; You \& Leung, 2012), except for the Persian study (Azizi, 2010). All these results show that the Regulation subscale might be a separate component from Distress Tolerance.

Based on these findings, we conducted a hierarchical CFA of the reduced model (C), without the Regulation subscale. We acquired significant and satisfactory factor loadings (see Table 1) and slightly better four out of six goodness of fit indices (see Table 2). The results of all the mentioned analyses support the three-factor structure of DT and treat Regulation as a separate factor, which does not confirm the four-factor structure proposed by Simons and Gaher (2005).

However, the conclusion about the psychometric properties of the Polish DTS version, either in the four- or three-factor solution, cannot be based solely on factor analysis and intercorrelations. As pointed out by Bedyńska and Książek (2012), the goodness of the model is not based only on the fit indices. The most 
important is its compatibility with the theory, which should be cohesive and possible to verify with various methods (Hornowska, 2009). To this end, we analyzed convergent and discriminant validity.

Based on the original assumptions (Simons \& Gaher, 2005), we expected (H2) a positive relationship of the DTS (both for the overall score and the subscales) with positive affectivity (Watson et al., 1988). Furthermore, we expected (H3) a positive association with the self-control ability (Tangney et al., 2004), and (H4) satisfaction with life (Diener et al., 1985). We tested those hypotheses both for the original model (A) and for the reduced, 3-factor model (C). They were supported only for the overall score and for three subscales: Tolerance, Appraisal, and Absorption. The higher the ability to tolerate distress and those three components, the higher positive affectivity, self-control ability, and satisfaction with life. Those variables explain a moderate range of variance of the overall score for both tested versions of the DTS. In the 4 -factor version (model A), it accounted for 1.96 to $9.61 \%$ of the variance, and 9.30 to $12.25 \%$ in the 3 -factor version (model C). Contrary to our assumptions, Regulation did not correlate significantly with the self-control ability and satisfaction with life, and it even correlated negatively with positive affectivity. Those are further arguments supporting the elimination of this subscale from the DTS.

The obtained results of the convergent validity analyses are in line with the original study (Simons \& Gaher, 2005) and with other adaptations (Azizi, 2010; You \& Leung, 2012; Sandín et al., 2017). They are also supported by the findings of other studies, in which being exposed to distress was related to reduced psychological well-being (Veit \& Ware, 1983) and deteriorated perceived quality of life (Bernstein et al., 2011). As shown by Tangney et al. (2004), self-control abilities protect the individual from experiencing distress. Also, Rosenbaum's study (1980) showed that individuals who declared a higher degree of self-control were able to withstand an unpleasant behavioral stimulus (e.g., cold) much longer than individuals declaring lower self-control ability. Generally, our findings confirm the convergent validity of measuring DT with the Polish version of the DTS.

To examine the discriminant validity, we expected the DTS and its subscales (H 5) to be negatively related to negative affectivity (Watson et al., 1988; Simons \& Gaher, 2005), (H6) perceived stress (Cohen \& Wiliamson, 1988), and (H7) difficulties in emotion regulation (Gratz \& Roemer, 2004). Generally, the conducted analyzes supported our hypotheses. The higher the distress tolerance, the lower negative affectivity, perceived stress, and difficulties in emotion regulation. Our findings are consistent with the other studies (Akbari, 2017; Azizi, 
2010; Brandt et al., 2013; Garey et al., 2015; Iverson et al., 2012; Simons \& Gaher, 2005), and confirm the discriminant validity of the Polish DTS. The mentioned variables accounted for 22 to almost $41 \%$ of the variance of the overall DTS score in the 4-factor solution, and from 26 to almost $49 \%$ of the variance in the 3-factor model. Moreover, contrary to the assumptions, the Regulation subscale did not correlate significantly with the perceived stress and with one of the DERS components - a lack of emotional clarity. A lack of emotional awareness, measured by DERS, did not correlate with the overall DTS score, nor with any of its subscales. It may not be connected to the ability to withstand distressing emotions, which is why there were no relationships between those variables. Among the components of difficulties in emotion regulation, there was a high negative correlation with a lack of knowledge on emotion regulation strategies and distress tolerance (see Table 3). In the 4-factor version, it explained almost $41 \%$ of the overall score variance, while in the 3 -factor version, it was almost $52 \%$. It should be noted that measuring limited access to emotion regulation strategies in DERS is related to the usage of constructive strategies, not to the knowledge of escape-avoidance strategies. This may be the reason why the Regulation subscale correlated very weakly with this variable $(r=-.17 ; p<.01)$. In general, the Regulation subscale was related to the DERS compounds on the weakest level, not exceeding approx. $7.3 \%$ of the explained variance. Similar results were also obtained in other versions of the DTS. In all of those studies, the Regulation subscale obtained much weaker relations to the validity variables than the other subscales (Sandín et al., 2017; Simons \& Gaher, 2005; Wagener \& Blairy, 2015; You \& Leung, 2012), except for the Persian study (Azizi, 2010).

Overall, the results mentioned above support the decision of excluding Regulation subscale from the adapted tool. This subscale, in many cases, did not correlate significantly with validity variables. When it did, they were very weak correlations, occasionally even contradicting the hypotheses. The matter of the Regulation subscale not meeting the theoretical validity criteria requires an explanation.

The findings of the reliability analyses for Regulation are satisfactory and do not deviate from the results of the other subscales (see Table 1). Similar to other studies, Regulation reached high-reliability coefficients (Azizi, 2010; Sandín et al., 2017; Simons \& Gaher, 2005; Wagener \& Blairy, 2015; You \& Leung, 2012). Nevertheless, the question arises if the operationalization of this variable is theoretically cohesive with the remaining DT constructs. This is indicated by the content of the items forming this subscale: "I'll do anything to avoid feeling distressed or upset," "I'll do anything to stop feeling distressed or upset," and 
"When I feel distressed or upset, I must do something about it immediately" (Simons \& Gaher, 2005). These statements reflect escape-avoidance behavior when experiencing unpleasant, distressing emotions. A negation of those items assumes the opposite behaviors like enduring, tolerating, or regulating them, reflecting the distress tolerance construct (Bardeen et al., 2013; Iverson et al., 2012; Leyro et al., 2010). However, refraining from using avoidant coping strategies does not automatically imply constructive coping. In this context, it becomes clear why the Regulation subscale has weak relationships with the indicators of difficulties in emotion regulation, especially limited access to emotion regulation strategies. To preserve the 4-factor structure proposed by the authors, it would be necessary to rephrase the items included in this subscale. The Regulation aspect of distress tolerance should relate to the ability to cope constructively and persistently with negative stress emotions, and the items ought to be phrased positively.

Moreover, we supported the hypothesis (H8) of gender differences in the DTS results (Sandín et al., 2017; Simons \& Gaher, 2005). As expected, men obtained higher scores than women on all subscales and overall DTS results (see Table 4). These findings suggest that men tolerate distress better than women. However, because DTS is a self-report tool, it should be noted that cultural demands on men, especially of higher stress resistance, may prompt them to make such declarations (Eisler \& Skidmore, 1987). To fully confirm the greater distress tolerance in men, it is necessary to carry out studies of these gender differences at a behavioral level, including various types of stressful, critical life events that cause psychological suffering and pain.

Finally, it should be noted that both validated versions of the Polish DTS (4-factor and 3-factor) demonstrated reliability parameters ranging from acceptable to very good: internal consistency, item-total correlation, and absolute temporal stability (see Table 1). Only the Regulation subscale in the 4-factor version obtained the weakest item-total correlation and temporal stability coefficients.

Some limitations of the described study ought to be discussed. Despite the large sample size, it consisted mainly of students. This limits the possibility of generalizing results to other social groups. It would also be valuable to know the relationship of distress tolerance with other mental health indicators and coping resources. To determine the prognostic and diagnostic validity of DTS, it is worth carrying out prospective studies of individuals who struggle with difficult and painful requirements of life regularly. It would be interesting to learn about individual differences in distress tolerance in those who are particularly exposed to it, such as emergency workers or soldiers participating in dangerous military 
missions. A certain weakness of our research was also the relatively short time of temporal stability tests, which was 2 weeks, compared to a 6-month break in the original research (Simons \& Gaher, 2005). Further studies of validity could also use more of the variables included in the original research on drinking alcohol or smoking. This issue has been taken up in numerous studies (Azizi, 2010; Carey \& Correia, 1997; Holzhauer et al., 2017; Kuntsche et al., 2005; Leventhal \& Zvolensky, 2015; Leyro et al., 2011; Shadur et al., 2017; Simons \& Gaher, 2005).

The DTS concept and tool should be used in research on issues related to coping with stress, resilience, coping resources, and mental health. The problem of distress tolerance is important for psychological practice. Psychologists encounter suffering and psychological pain while working with people who are sick, in crises, and going through traumatic experiences. Thus, a good theoretical specification of the construct of distress tolerance and its adequate operationalization may provide grounds for a valuable tool that is helpful in psychological practice. However, to be able to serve psychological practice, the DTS needs a revision of the theoretical assumptions and a new version of validation on a suitably broad and representative sample that would allow the normalization of the method.

In conclusion, the results of all our analyses and the findings of other studies about distress tolerance have led us to recommend the 3 -factor version as more cohesive and valid than the original. The reduced, 3 -factor, Polish version of the Distress Tolerance Scale is a valid and reliable method of measuring distress tolerance and its components: tolerance, appraisal, and absorption. We present the items and psychometric properties of both versions in the article, thus leaving up to the reader the decision of which version they would prefer to use for the best results of their research goals.

\section{REFERENCES}

Akbari, M. (2017). Metacognitions of distress intolerance: The mediating role in the relationship between emotional dysregulation and problematic internet use. Addictive Behaviors Reports, 6, 128-133. https://doi.org/10.1016/j.abrep.2017.10.004

Azizi, A. R. (2010). Reliability and validity of the Persian version of Distress Tolerance Scale. Iranian Journal of Psychiatry, 5(4), 154-158.

Bardeen, J. R., Fergus, T. A., \& Orcutt, H. K. (2013). Testing a hierarchical model of distress tolerance. Journal of Psychopathology and Behavioral Assessment, 35(4), 495-505. https://doi.org/10.1007/s10862-013-9359-0 
Bedyńska, S., \& Książek, M. (2012). Statystyczny drogowskaz 3: Praktyczny przewodnik wykorzystania modeli regresji oraz równań strukturalnych [Statistical guidepost: Vol. 3, A practical guide to the use of regression models and structural equations]. Sedno.

Bernstein, A., Marshall, E. C., \& Zvolensky, M. J. (2011). Multi-method evaluation of distress tolerance measures and construct(s): Concurrent relations to mood and anxiety psychopathology and quality of life. Journal of Experimental Psychopathology, 2(3), 386399. https://doi.org/10.5127/jep.006610

Brandt, C. P., Zvolensky, M. J., \& Bonn-Miller, M. O. (2013). Distress tolerance, emotion dysregulation, and anxiety and depressive symptoms among HIV+ individuals. Cognitive Therapy and Research, 37(3), 446-455. https://doi.org/10.1007/s10608-012-9497-9

Brown, R. A., Lejuez, C. W., Kahler, C. W., Strong, D. R., \& Zvolensky, M. J. (2005). Distress tolerance and early smoking lapse. Clinical Psychology Review, 25(6), 713-733. https://doi. org/10.1016/j.cpr.2005.05.003

Brzozowski, P. (2010). Skala Uczuć Pozytywnych i Negatywnych SUPIN. Polska adaptacja skali PANAS Davida Watsona i Lee Anny Clark: Podręcznik [Positive and Negative Affect Scale. A Polish adaptation of David Watson's and Lee Anne Clark's PANAS scale: A handbook.]. Pracownia Testów Psychologicznych Polskiego Towarzystwa Psychologicznego.

Carey, K. B., \& Correia, C. J. (1997). Drinking motives predict alcohol-related problems in college students. Journal of Studies on Alcohol, 58(1), 100-105. https://doi.org/10.15288/jsa.1997. 58.100

Cohen, S., \& Wiliamson, G. (1988). Perceived stress in a probability sample of the United States. In S. Spacapan \& S. Oskamp (Eds.), The Claremont Symposium on Applied Social Psychology. The social psychology of health (pp. 31-67). Sage Publications.

Diener, E., Emmons, R. A., Larsen, R. J., \& Griffin, S. (1985). The Satisfaction With Life Scale. Journal of Personality Assessment, 49(1), 71-75. https://doi.org/10.1207/s15327752jpa4901_13

Dragan, M. (2016). Problemowe picie alkoholu przez mlode kobiety. Rola niekorzystnych doświadczeń i samoregulacji emocji [Problematic alcohol use among young women. The role of adverse experiences and emotion regulation]. Scholar.

Eisler, R. M., \& Skidmore, J. R. (1987). Masculine gender role stress. Behavior Modification, 11(2), 123-136. https://doi.org/10.1177/01454455870112001

Garey, L., Bakhshaie, J., Sharp, C., Neighbors, C., Zvolensky, M. J., \& Gonzalez, A. (2015). Anxiety, depression, and HIV symptoms among persons living with HIV/AIDS: The role of hazardous drinking. AIDS Care, 27(1), 80-85. https://doi.org/10.1080/09540121.2014.956042

Gratz, K. L., \& Roemer, L. (2004). Multidimensional assessment of emotion regulation and dysregulation: Development, factor structure, and initial validation of the difficulties in Emotion Regulation Scale. Journal of Psychopathology and Behavioral Assessment, 26(1), 41-54. https://doi.org/10.1023/B:JOBA.0000007455.08539.94

Holzhauer, C. G., Wemm, S., \& Wulfert, E. (2017). Distress tolerance and physiological reactivity to stress predict women's problematic alcohol use. Experimental and Clinical Psychopharmacology, 25(3), 156-165. https://doi.org/10.1037/pha0000116

Hornowska, E. (2009). Testy psychologiczne. Teoria i praktyka [Psychological tests. Theory and practice]. Scholar.

Hornowska, E., \& Paluchowski, W. (2004). Problemy adaptacji kulturowej testów [Problems of cultural adaptation of tests]. In J. Brzeziński (Ed.), Metodologia badań psychologicznych [Methodology of psychological research] (pp. 576-595). PWN. 
Iverson, K. M., Follette, V. M., Pistorello, J., \& Fruzzetti, A. E. (2012). An investigation of experiential avoidance, emotion dysregulation, and distress tolerance in young adult outpatients with borderline personality disorder symptoms. Personality Disorders: Theory, Research, and Treatment, 3(4), 415-422. https://doi.org/10.1037/a0023703

Juczyński, Z. (2001). Skala Satysfakcji z Życia [Satisfaction with Life Scale]. In Narzędzia pomiaru $w$ promocji $i$ psychologii zdrowia [Measurement tools in the promotion of health and health psychology]. Pracownia Testów Psychologicznych Polskiego Towarzystwa Psychologicznego.

Juczyński, Z., \& Ogińska-Bulik, N. (2009). PSS-10 - Skala Odczuwanego Stresu [PSS-10 Perceived Stress Scale]. In Narzędzia Pomiaru Stresu i Radzenia Sobie ze Stresem [Tools for measuring stress and coping with stress]. Pracownia Testów Psychologicznych Polskiego Towarzystwa Psychologicznego.

Keough, M. E., Riccardi, C. J., Timpano, K. R., Mitchell, M. A., \& Schmidt, N. B. (2010). Anxiety symptomatology: The association with distress tolerance and anxiety sensitivity. Behavior Therapy, 41(4), 567-574. https://doi.org/10.1016/j.beth.2010.04.002

Kuntsche, E., Knibbe, R., Gmel, G., \& Engels, R. (2005). Why do young people drink? A review of drinking motives. Clinical Psychology Review, 25(7), 841-861. https://doi.org/10.1016/ j.cpr.2005.06.002

Leventhal, A. M., \& Zvolensky, M. J. (2015). Anxiety, depression, and cigarette smoking: A transdiagnostic vulnerability framework to understanding emotion-smoking comorbidity. Psychological Bulletin, 141(1), 176-212. https://doi.org/10.1037/bul0000003

Leyro, T. M., Bernstein, A., Vujanovic, A. A., McLeish, A. C., \& Zvolensky, M. J. (2011). Distress Tolerance Scale: A confirmatory factor analysis among daily cigarette smokers. Journal of Psychopathology and Behavioral Assessment, 33(1), 47-57. https://doi.org/10.1007/s10862010-9197-2

Leyro, T. M., Zvolensky, M. J., \& Bernstein, A. (2010). Distress tolerance and psychopathological symptoms and disorders: A review of the empirical literature among adults. Psychological Bulletin, 136(4), 576-600. https://doi.org/10.1037/a0019712

McHugh, R. K., \& Otto, M. W. (2012). Refining the measurement of distress intolerance. Behavior Therapy, 43(3), 641-651. https://doi.org/10.1016/j.beth.2011.12.001

Poprawa, R. (2016). Polska adaptacja Skali Impulsywnego Zachowania UPPS-P oraz jej znaczenie w predykcji wybranych eksternalizowanych problemów i zaburzeń [A Polish adaptation of the UPPS-P Impulsive Behavior Scale and its significance in the prediction of selected externalised problems and disorders]. Przeglad Psychologiczny, 59(1), 95-116.

Rosenbaum, M. (1980). Individual differences in self-control behaviors and tolerance of painful stimulation. Journal of Abnormal Psychology, 89(4), 581-590. https://doi.org/10.1037/0021843X.89.4.581

Sandín, B., Simons, J. S., Valiente, R. M., Simons, R. M., \& Chorot, P. (2017). Psychometric properties of the Spanish version of the distress tolerance scale and its relationship with personality and psychopathological symptoms. Psicothema, 29(3), 421-428. https://doi.org/ 10.7334/psicothema2016.239

Schreiber, J. B., Nora, A., Stage, F. K., Barlow, E. A., \& King, J. (2006). Reporting structural equation modeling and confirmatory factor analysis results: A review. The Journal of Educational Research, 99(6), 323-338. https://doi.org/10.3200/JOER.99.6.323-338 
Shadur, J. M., Ninnemann, A. L., Lim, A., Lejuez, C. W., \& MacPherson, L. (2017). The prospective relationship between distress tolerance and cigarette smoking expectancies in adolescence. Psychology of Addictive Behaviors, 31(5), 625-635. https://doi.org/10.1037/ adb0000300

Simons, J. S., \& Gaher, R. M. (2005). The Distress Tolerance Scale: Development and validation of a self-report measure. Motivation and Emotion, 29(2), 83-102. https://doi.org/10.1007/ s11031-005-7955-3

TIBCO Software Inc. (2020). Data Science Textbook. https://docs.tibco.com/data-science/textbook

Tangney, J. P., Baumeister, R. F., \& Boone, A. L. (2004). High self-control predicts good adjustment, less pathology, better grades, and interpersonal success. Journal of Personality, 72(2), 271-324. https://doi.org/10.1111/j.0022-3506.2004.00263.x

Veit, C. T., \& Ware, J. E. (1983). The structure of psychological distress and well-being in general populations. Journal of Consulting and Clinical Psychology, 51(5), 730-742. https://doi.org/ 10.1037/0022-006X.51.5.730

Wagener, A., \& Blairy, S. (2015). Version française de la Distress Tolerance Scale et de la Discomfort Intolerance Scale. Canadian Journal of Behavioural Science/Revue Canadienne Des Sciences Du Comportement, 47(3), 241-250. https://doi.org/10.1037/cbs0000015

Watson, D., Clark, L. A., \& Tellegen, A. (1988). Development and validation of brief measures of positive and negative affect: The PANAS scales. Journal of Personality and Social Psychology, 54(6), 1063-1070. https://doi.org/10.1037/0022-3514.54.6.1063

You, J., \& Leung, F. (2012). A Chinese adaptation of the Distress Tolerance Scale among adolescents: Factor structure and psychometric properties. Journal of Psychopathology and Behavioral Assessment, 34(1), 136-144. https://doi.org/10.1007/s10862-011-9256-3 